\title{
ANALISIS DAMPAK RENCANA PENERAPAN ISAK 16: PENYELENGGARAAN PRASARANA KERETA API RINGAN/LIGHT RAIL TRANSIT
}

\author{
Bambang Budi Prasetyo \\ 1bambang.2budi.3prasetyo@gmail.com \\ Universitas Airlangga, Surabaya \\ Dian Agustia \\ agustia.dian@yahoo.com \\ Universitas Airlangga, Surabaya
}

\begin{abstract}
The purpose of this research is to analyze the impact of the implementation plan of ISAK 16 by KAI, the other purpose of this research is to discuss what issues might be faced by $\mathrm{KAI}$ in the plan to implement ISAK 16. This type of research is qualitative research using descriptive research method. The study found that the implementation plan of ISAK 16 by KAI will have an impact on accounting problems, the problems that will be faced are the problems of revenue recognition to construction services, the decline in the value of intangible assets and the recognition of fixed assets. Based on the impact of the implementation plan of ISAK 16 by KAI, the recognition of revenues to construction services can be fiscal corrected, the decline in the value of intangible assets can be minimized by continuing to generate future cash flows from subsequent use of assets or other assets and ask for clarification and affirmation to Dewan Standar Akuntansi Keuangan (DSAK) on the issue of recognition of property and equipment.
\end{abstract}

Keywords: Infrastructure, Concession Agreement, Light Rail Trasit

\section{PENDAHULUAN}

Salah satu permasalahan yang harus diselesaikan di Jakarta saat ini adalah kemacetan. Kemacetan ini disebabkan salah satunya adalah karena adanya urbanisasi. Urbanisasi ini menyebabkan bertambahnya jumlah penduduk di Jakarta. Dengan bertambahnya jumlah penduduk, secara tidak langsung akan menaikkan tingkat kebutuhan akan transportasi. Kebutuhan akan transportasi inilah yang kemudian mendorong masyarakat untuk memenuhi kebutuhan transportasi dengan melakukan pembelian alat transportasi. Berbagai upaya telah dilakukan oleh pemerintah baik Pemerintah pusat maupun Pemerintah Provinsi Jakarta untuk mengurangi kemacetan, diantaranya adalah dengan mengoperasikan Transjakarta. Sampai saat ini sudah memilki peningkatan yang cukup signifikan dan sudah banyak dijadikan transportasi utama bagi sebagian warga Jakarta dan sekitarnya. Hal ini adalah suatu yang baik, 
namun jangan sampai membuat semua lupa bahwa transportasi masal yang berupa bus ini bukanlah yang utama dalam perancangan transportasi Jakarta di masa depan. Bus tidak bisa menjadi tulang punggung bagi pergerakan komuter di kota besar. Kenyataannya, bus tidak bisa mengangkut penumpang lebih banyak dibandingkan dengan transportasi berbasis rel. Selain itu, bus juga melewati jalur yang sama dengan mobil pribadi, yang berarti ada hambatan yang sama baik itu macet, lampu merah, atau bahkan berhenti karena ada yang asal menyeberang.

Dalam upayanya untuk mengurangi kemacetan ibukota, saat ini pemerintah telah membuat kebijakan transportasi Jakarta ke arah transportasi berbasis rel. Dimulai dari tahun 2011 dimana Pemprov Jakarta telah memulai pembangunan proyek MRT dan kemudian di tahun 2015dengan tujuan untuk meningkatkan pelayanan transportasi, Pemerintah Pusat telah mengeluarkanPeraturan Presiden Republik Indonesia Nomor 98 tahun 2015 tentang Percepatan Penyelenggaraan Kereta Api Ringan/Light Rail Transit Terintegrasi Di Wilayah Jakarta, Bogor, Depok, dan Bekasi. Percepatan penyelenggaraan kereta api ringan ini diharapkan bisa mengurangi kemacetan yang terjadi di Jakarta. Guna mengurangi beban APBN atas percepatan penyelenggaraan kereta api ringan dan memberikan alternatif pendanaan atas proyek penyelenggaraan kereta api ringan, Pemerintah Pusat melakukan perubahan atas Peraturan Presiden Republik Indonesia Nomor 98 tahun 2015. Perubahan ini tertuang dalam Peraturan Presiden Republik Indonesia Nomor 49 Tahun 2017 tentang Perubahan Kedua Atas Peraturan Presiden Nomor 98 Tahun 2015 tentang Percepatan Penyelenggaraan Kereta Api Ringan/Light Rail Transit Terintegrasi Di Wilayah Jakarta, Bogor, Depok, dan Bekasi. Perubahan utama atas Peraturan Presiden ini adalah pembayaran atas pembangunan prasarana yang dibangun oleh PT Adhi Karya (Persero) Tbk. dilakukan melalui PT Kereta Api Indonesia (Persero) atau KAI, selain itu terdapat penugasan Pemerintah kepada KAI yang meliputi, penyelenggaraan pengoperasian prasarana, perawatan prasarana, dan pengusahaan prasarana termasuk pendanaan pembangunan prasarana Kereta Api Ringan/ Light Rail Transit terintegrasi.

Melalui Keputusan Menteri Perhubungan Nomor KP 989 tahun 2017 tanggal 13 November 2017 telah ditetapkan KAI sebagai Badan Usaha penyelenggara prasarana Kereta Api Ringan/Light Rail Transit dansesuai pasal 307 Peraturan Pemerintah Republik Indonesia Nomor 56 Tahun 2009 tentang Penyelenggaraan Perkeretaapian, dalam hal suatu Badan Usaha telah diberikan hak penyelenggaraan prasarana perkeretaapian umum maka hak penyelenggaraan prasarana perkeretaapian umum harus dituangkan dalam perjanjian penyelenggaraan prasarana perkeretaapian umum antara Menteri, gubernur, atau bupati/walikota sesuai kewenangannya dan Badan Usaha. Untuk melaksanakan pasal 307 PP 56/2009, Pemerintah melalui Direktorat Jenderal Perkeretaapian Kementerian Perhubungan menuangkan hak penyelenggaraan prasarana perkeretaapian umum dalam suatu perjanjian.Pemberian hak penyelenggaraan ini diaturdalam pasal 31 angka (3) Peraturan Menteri Perhubungan Republik Indonesia Nomor PM 15 tahun 2016 tentang Konsesi dan Bentuk Kerjasama Lainnya antara Pemerintah dan Badan Usaha di Bidang Perkeretaapian Umum, dimana hak penyelenggaraan yang berupa hak konsensi diberikan 
paling lama 50 tahun. Selain mendapatkan hak konsensi, KAI juga berhak melakukan pengenaan tarif kepada masyarakat sebagai pengguna jasa, hal ini sesuai pasal 396 huruf (2) Peraturan Pemerintah Republik Indonesia Nomor 56 Tahun 2009 tentang Penyelenggaraan Perkeretaapian disebutkan bahwa masyarakat yang mendapatkan pelayanan penyelenggaraan perkeretaapian harus membayar atas pelayanan yang dinikmati sesuai dengan tarif yang diberlakukan oleh penyelenggara perkeretaapian.

Sesuai dengan pasal 307 Peraturan Pemerintah Republik Indonesia Nomor 56 Tahun 2009 tentang Penyelenggaraan Perkeretaapian, maka hak penyelenggaraan prasarana perkeretaapian umum harus dituangkan dalam perjanjian penyelenggaraan prasarana perkeretaapian umum.Merujuk pasal 31 angka (2) huruf c dan e perjanjian paling sedikit harus memuat masa konsensi pengusahaan, tarif awal dan formula penyesuaian tarif. Berdasarkan hal tersebut diatas perjanjian penyelenggaraan prasaranaKereta Api Ringan dapat diartikan bahwa perjanjian tersebut adalah termasuk dalam perjanjian konsesi jasa yang dimaksud dalam Interpretasi Standar Akuntansi Keuangan 16 (ISAK 16) yaitu perjanjian konsensi jasa. Konsekuensi atas perjanjian tersebut adalah KAI diharuskan menerapkan ketentuan ISAK 16 dalam Laporan Keuangannya. Penerapan ISAK 16 dalam laporan keuangan KAI akan mengakibatkan dampak yang signifikan terhadap penyajian laporan posisi keuangan dan rasio keuangan perusahaan. Hal ini dikarenakan terjadi perubahan kebijakan akuntansi dari KAI. Dengan penerapan ISAK 16, KAI hanya dapat mengakui aset keuangan/piutang atau aset tidak berwujud atas pendapatan yang diterima dan tidak dapat mengakui infrastruktur prasarana sebagai aset tetap.

Berdasarkan uraian diatas, maka dalam penelitian ini akan menganalisis dampak dari rencana penerapan ISAK 16 oleh KAI, selain itu penelitian ini bertujuan untuk melakukan pembahasan mengenai permasalahan-permasalahan dan isu-isu apa sajakah yang mungkin akan dihadapi oleh KAI dalam rencana mengimplementasikan ISAK 16.

\section{LANDASAN TEORI}

Pemerintah telah memperkenalkan perjanjian jasakontraktual untuk menarik partisipasi sektor swasta dalampembangunan, pembiayaan, pengoperasian dan pemeliharaaninfrastruktur. Infrastruktur tersebut mungkin sudahtersedia, atau mungkin harus dibangun selama periodeperjanjian jasa. Perjanjian jasaini biasanya melibatkan entitas sektor swasta (operator) untukmembangun infrastruktur yang digunakan untuk menyediakanlayanan publik atau meningkatkannya (misalnya, denganmeningkatkan kapasitas) dan mengoperasikan sertamemelihara infrastruktur tersebut untuk jangka waktutertentu. Operator dibayar untuk jasa yang diberikan selamaperiode perjanjian. Perjanjian diatur oleh suatu kontrak yangmenetapkan standar kinerja, mekanisme penyesuaian harga,dan perjanjian untuk menengahi perselisihan. Perjanjiansemacam itu sering disebut Kerjasama Pemerintah Swasta.

PII (2014) mendefinisikan Kerjasama Pemerintah Swasta sebagai suatukontrak jangka panjang antara suatu pihak swasta dan suatu badan pemerintah untuk 
menyediakansuatu aset atau layanan publik, dan berdasarkan kontrak tersebut, pihak swasta menanggung risikosignifikan dan tanggung jawab pengelolaan dengan remunerasi yang ditentukan berdasarkan kinerja.

DSAK (2017a) mendefinisikan Kerjasama Pemerintah Swasta sebagai Perjanjian Konsesi Jasa yaitu perjanjian jasa kontraktual untuk menarik partisipasi sektor swasta dalam pengembangan, pembiayaan, pengoperasian, dan pemeliharaan infrastruktur. Selanjunya pedoman perjanjian konsesi jasa tersebut dituangkan dalam Interpretasi Standar Akuntansi Keuangan 16 (ISAK 16): Perjanjian Konsesi Jasa.

\subsection{Interpretasi Standar Akuntansi Keuangan 16 (ISAK 16)}

ISAK 16 adalah panduan yang mengatur akuntansi untuk operator atas perjanjian konsensi jasa publik ke swasta. Yang dimaksud dengan operator untuk tujuan penulisan ini yaitu KAI yang diberikan hak penyelenggaraan prasarana perkeretaapian umumdan untuk berpartisipasi dalam pembangunan, pembiayaan, pengoperasian dan pemeliharaan insfrastruktur. Yang dimaksud infrastruktur ialah aset tetap yang digunakan untuk pelayanan kepada publik, seperti aset prasarana, aset fasilitas perawatan prasarana, dan aset fasilitas perawatan sarana. Yang disebut sebagai grantor/pemberi konsensi untuk tujuan penulisan ini yaitu Kementerian Perhubungan sebagai wakil dari pemerintah, selain itu grantor juga dapat didefinisikan sebagai pihak yang memberikan hak kepada operator untuk memberikan pelayanan jasa kepada publik melalui perjanjian konsensi jasa.

ISAK 16 menyebutkan beberapa ciri-ciri dalam perjanjian konsensi jasa antara lain sbb:

1. Kewajiban melayani Publik ada pada Operator;

2. Pemberi konsensi (grantor) adalah entitas sektor publik atau entitas swasta yang telah diberi tanggung jawab;

3. Operator bertanggung jawab setidaknya atas sebagian pengelolaan infrastruktur dan jasa terkait, tidak hanya sebagai agen dari grantor;

4. Kontrak menetapkan harga awal yang akan dikenakan oleh operator dan mengatur perubahan harga selama periode perjanjian jasa;

5. Operator wajib menyerahkan infrastruktur kepada grantor pada akhir masa konsensi.

Selain menyebutkan ciri-ciri dalam perjanjian konsensi jasa, ISAK 16 juga meringkas perlakuan akuntansi untuk perjanjian konsensi jasa yang tertuang dalam kerangka akuntansi pada gambar 1. 


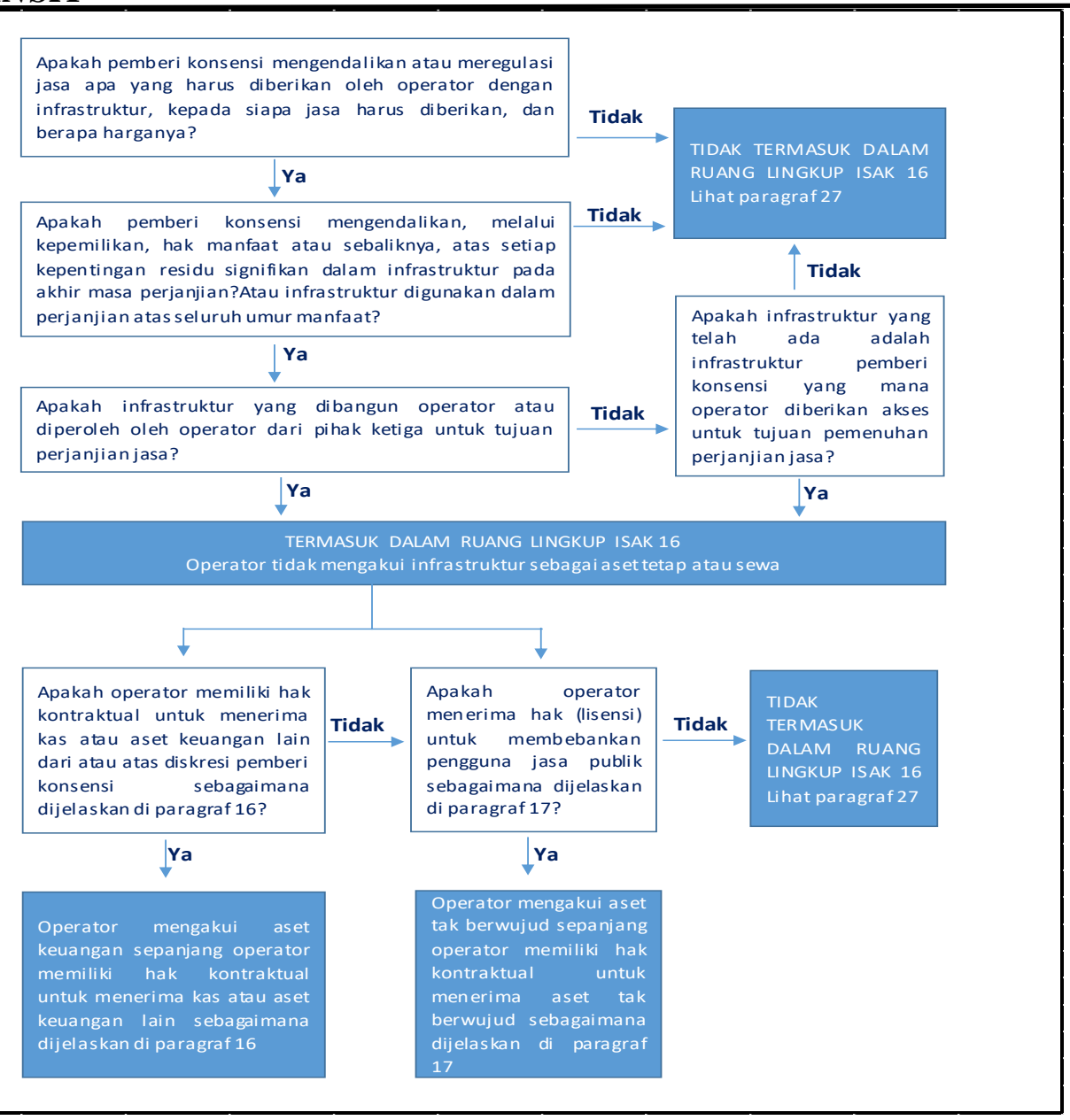

Gambar 1 Kerangka akuntansi untuk Perjanjian Konsensi Jasa Publik ke Swasta

Sumber: DSAK (2017a)

\subsection{Penelitian Terdahulu}

Berikut ini adalah beberapa ringkasan penelitian terdahulu sehubungan dengan topikpenelitian ini:

1. Penelitian Komives (2001) yang berjudul Designing Propoor Water And Sewer Concessions: Early Lessons From Bolivia, masalah dalam penelitian ini adalah bagaimana pemerintah Bolivia meningkatkan penyediaan air dan sanitasi di daerah dengan pendapatan rendah dengan perjanjian konsesi jasa agar tidak berdampak pada obligasi, kemampuandan financial insentive dari penyediaan jasa tersebut. Hasil penelitian menunjukkan bahwa untuk melakukan perjanjian konsesi tersebut, pemerintah harus berhati-hati membuat perjanjian konsesi jasa agar tidak berdampak pada obligasi, kemampuan dan financial incentive dari penyediaan jasa tersebut. Dengan demikian pemerintah harusmemperjelas objek kontrak dan membuatnya mudah diukur, mengeleminasi kebijakan yang menghalangi penyediaan layanan bagi orang miskin, serta membuat financial insentive yang konsisten dengan memperluas pelayanan jasa. 
2. Penelitian Bousquet dan Fayard (2001) yang berjudul Road Infrastructure Concession Practice In Europe, masalah dalam penelitian ini adalah Bagaimana perjanjian konsesi jasa mensukses-kan implementasi proyek konsesi infrastruktur jalan di Eropa. Hasil penelitian menunjukkan bahwa sebagian besar negara-negara di Eropa telah menggunakan perjanjian konsesi jasa dalam menyediakan infrastruktur jalan. Penyediaan infrastruktur jalan dianggap lebih adil menggunakan perjanjian konsesi jasa karena pendapatan dari konsesi jasa jelas, yaitu dari pengguna jalan, sedangkan bila tidak menggunakan perjanjian konsesi jasa, maka sumber dana diperoleh dari pembayar pajak. Kepemilikan jalan pun menjadi milik pemerintah, bukan swasta bila menggunakan perjanjian konsesi jasa.

3. Penelitian Moretto dan Dosi (2007) yang berjudul Concession Bidding Rules And Investment Time Flexibility, masalah dalam penelitian ini adalah menguji dua macamperjanjian konsesi jasa yang ditawarkan yaitu pendapatan dari konsumen atau menerima pembayaran dari pemeritah untuk menentukan mana yanglebih menguntungkan. Hasil penelitian menunjukkan bahwa baik pendapatan dari konsumen maupun menerima pembayaran dari pemerintah ternyata hasil akhirnya sama. Yang menentukan mana yang lebih menguntungkan bukanlah jenisperjanjian konsesi yang ditawarkan melainkan waktu yang mudah diatur yang memberikan nilai yang lebih tinggi.

4. Penelitian Frans, Ginting, dan Riwoe (2014) yang berjudul Perjanjian Konsesi Jasa: Studi Kasus Perhitungan ISAK 16 di PT. Telkom, penelitian ini meneliti mengenai dampak perubahan perlakuan akuntansi dari perjanjian PT. Telkom dengan Menkominfo yang sebelumnya diperlakukan sebagai kerjasama operasi menjadi perjanjian konsesi jasa dimana perubahan tersebut berdampak pada pendapatan dan aset tetap yang dimiliki oleh PT. Telkom. Hasil penelitian menunjukkan bahwa pemberlakuan ISAK 16 pada awal tahun 2012 membuat PT. Telkom harus melakukan perubahan perlakuan akuntansi pada setiap perjanjian konsesi jasa yang masih berlaku. Perubahan perlakuan akuntansi tersebut ternyata membuat PT. Telkom tidak mengakui adanya perolehan aset tetap atas perjanjian tersebut pada saat penyediaan jasa infrastruktur, serta perolehan pendapatan berupa aset keuangan dan/atau aset tidak berwujud atas penyediaan jasa operasi diakui hanya selama masa perjanjian konsesi jasa.

5. Penelitian Melati dan Christine Tjen (2015) yang berjudul Analisis Dampak Penerapan ISAK 16: Perjanjian Konsesi Jasa terhadap Pajak Penghasilan Perusahaan IPP. Penelitian ini meneliti mengenai dampak penerapan ISAK 16 terhadap Pajak Penghasilan Perusahaan IPP. Hasil penelitian menunjukkan bahwa Penerapan ISAK 16: Perjanjian Konsesi pada laporan keuangan perusahaan Independent Power Producer (IPP) menyebabkan perubahan pada pengakuan pendapatan, aset tetap dan beban depresiasi.

\section{METODE PENELITIAN}

Metode dalam penelitian ini menggunakan metode penelitian kualitatif deskriptif. Setyosari (2010) menjelaskan penelitian deskriptif adalah penelitian yang 
tujuannya untuk menjelaskan atau mendeskripsikan suatu peristiwa, keadaan, objek apakah orang, atau segala sesuatu yang terkait dengan variabel-variebel yang bisa dijelaskan baik menggunakan angka-angka maupun kata-kata.

\section{KERANGKA KONSEPTUAL}

Kerangka konseptual merupakan model yang menerangkan hubungan antara teoridengan faktor-faktor dalam suatu masalah yang telah diketahui, serta menghubungkanvariable-variabel penelitian yaitu variable bebas terikat (Sugiyono, 2004).

Penelitian ini meneliti mengenai dampak dari rencana penerapan ISAK 16 dalam Perjanjian Penyelenggaraan Prasarana Kereta Api Ringan/Light Rail Transit dimana perjanjian tersebut kemungkinan akan berdampak pada permasalahan akuntansi di KAI. Kerangka konseptual untuk menjelaskan masalah tersebut dapat terlihat dari gambar di bawah ini:

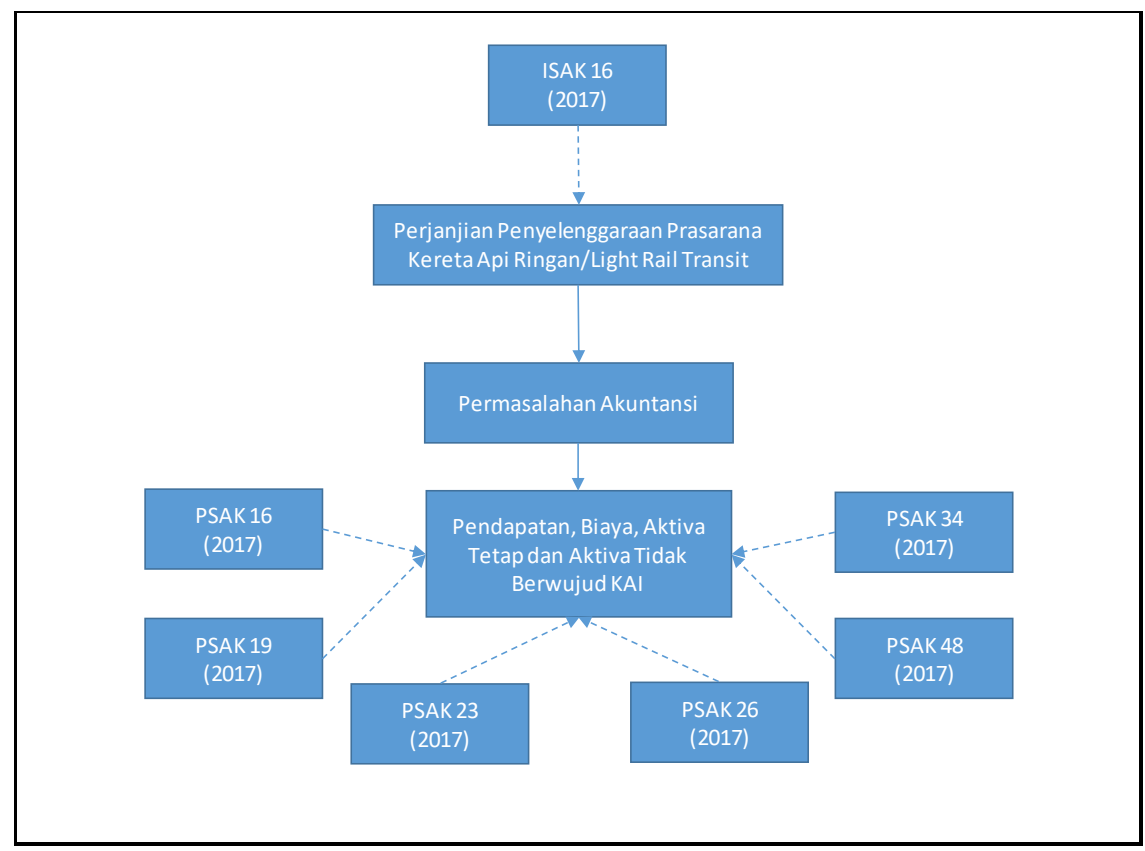

Gambar 2 Kerangka Konseptual Penelitian

\section{HASIL DAN PEMBAHASAN}

Perjanjian penyelenggaraan prasarana kereta api ringan/light rail transit adalah perjanjian yang timbul sebagai konsekuensi dari terbitnya Peraturan Presiden Republik Indonesia Nomor 49 Tahun 2017 tentang Perubahan Kedua Atas Peraturan Presiden Nomor 98 Tahun 2015 tentang Percepatan Penyelenggaraan Kereta Api Ringan/Light Rail Transit Terintegrasi Di Wilayah Jakarta, Bogor, Depok, dan Bekasi. Selain itu, perjanjian ini timbul dikarenakan adanya Peraturan Menteri Perhubungan Republik 
Indonesia Nomor PM 15 tahun 2016 tentang Konsesi dan Bentuk Kerjasama Lainnya antara Pemerintah dan Badan Usaha di Bidang Perkeretaapian Umum dan Peraturan Pemerintah Republik Indonesia Nomor 56 Tahun 2009 tentang Penyelenggaraan Perkeretaapian.

Dalam Peraturan Presiden Republik Indonesia Nomor 49 Tahun 2017 disebutkan bahwa Pemerintah menugaskan PT Adhi Karya (Persero) Tbk sebagai kontraktor EPC (engineering, procurement and construction) untuk membangun prasarana Kereta Api Ringan/ Light Rail Transit, yang dimaksud prasarana disini adalah jalur termasuk konstruksi jalur layang, stasiun, fasilitas operasi dan depo. Sedangkan KAI dalam Perpres tersebut ditetapkan sebagai investor dari proyek sehingga segala akibat biaya yang timbul dari adanya proyek tersebut menjadi tanggungjawab KAI. Dalam hal pendanaan Perpres juga mengatur bahwa sumber pendanaan KAI bisa didapatkan melalui Penyertaan Modal Negara, penerusan pinjaman dari Pinjaman Pemerintah yang berasal dari luar negeri dan/atau dalam negeri, penerbitan obligasi oleh KAI, pinjaman KAI dari lembaga keuangan termasuk lembaga keuangan multilateral, dan/atau bersumber dari pendanaan lainnya. Kompensasi yang diperoleh KAI atas Perpres tersebut adalah ditetapkannya KAI sebagai Badan Usaha penyelenggara prasarana Kereta Api Ringan/Light Rail Transit, bentuk kompensasi adalah berupa hak penyelenggaraan prasarana perkeretaapian umum maksimal selama 50 tahun. Penerbitan hak penyelenggaraan ini sesuai dengan pasal 307 Peraturan Pemerintah Republik Indonesia Nomor 56 Tahun 2009 tentang Penyelenggaraan Perkeretaapian dan Peraturan Menteri Perhubungan Republik Indonesia Nomor PM 15 tahun 2016 tentang Konsesi dan Bentuk Kerjasama Lainnya antara Pemerintah dan Badan Usaha di Bidang Perkeretaapian Umum. Selain kompensasi berupa hak penyelenggaraan prasarana perkeretaapian umum, KAI juga menerima dan mengelola pendapatan tarif yang diperoleh dari penyelenggaraan prasarana, namun besaran tarif sebelumnya telah ditentukan oleh Menteri Perhubungan. Untuk lebih jelasnya disajikan dalam gambar 3 mengenai hubungan antara KAI dengan Pemerintah dan pihak terkait lainnya dalam suatu skema bisnis berdasarkan Perjanjian Penyelenggaraan Prasarana Kereta Api Ringan/Light Rail Transit. 


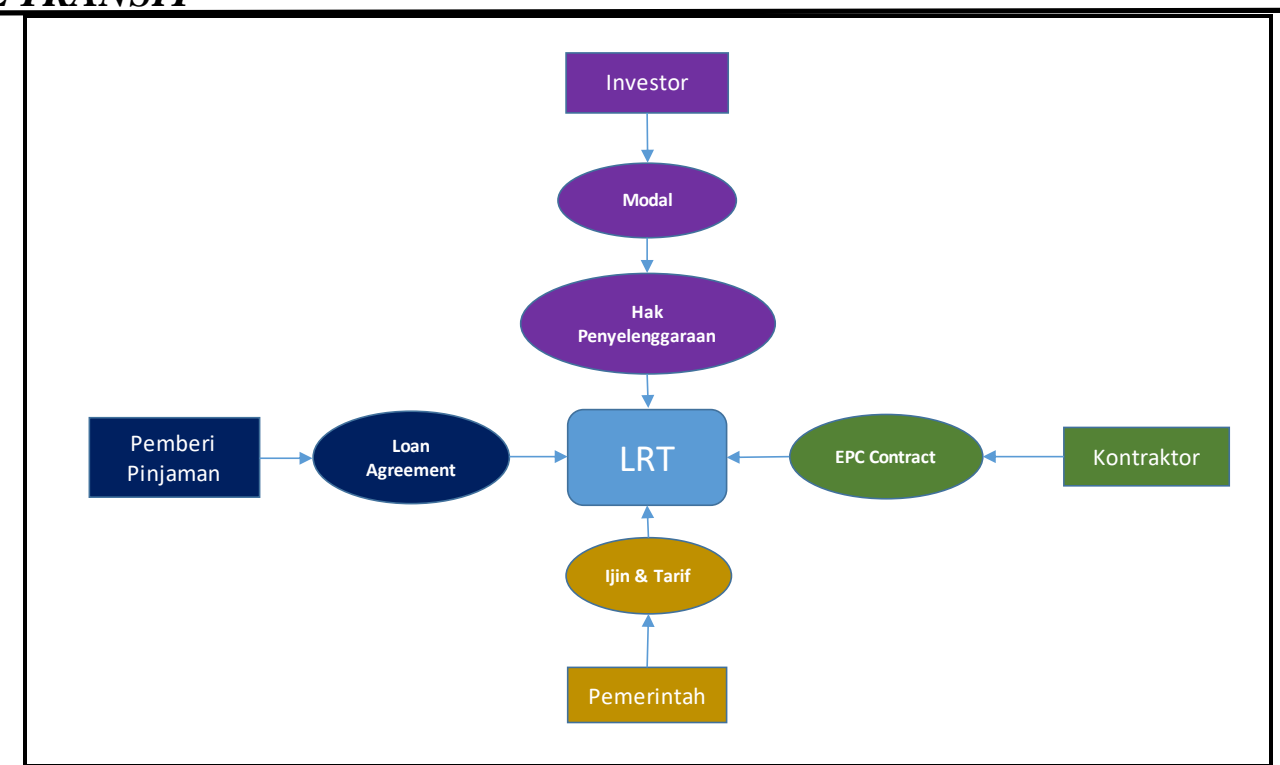

Gambar 3. Hubungan Pemerintah, KAI dan Pihak Terkait Sehubungan dengan

Perjanjian Penyelenggaraan Prasarana Kereta Api Ringan

Berdasarkan ciri-ciri dalam perjanjian konsensi jasa dan kerangka akuntansi pada gambar 1, bahwa atas perjanjian Penyelenggaraan Prasarana Kereta Api Ringan dapat dikatakan telah memenuhi persyaratan untuk menerapkan ISAK 16: Perjanjian Konsensi Jasa. Adapun alasan perjanjian Penyelenggaraan Prasarana Kereta Api Ringan termasuk dalam perjanjian konsensi jasa adalah sebagai berikut:

1. Pemerintah selaku grantor mengendalikan atau meregulasi jasa apa yang harus diberikan oleh operator dengan infrastruktur, kepada siapa jasa harus diberikan, dan berapa harganya;

2. Infrastruktur yang dibangun operator atau diperoleh oleh operator dari pihak ketiga untuk tujuan perjanjian jasa;

3. KAI akan menyerahkan seluruh infrastruktur kepada Pemerintah pada akhir masa perjanjian;

4. KAI bertanggung jawab atas pengelolaan infrastruktur dan jasa terkait;

5. KAI mempunyai kewajiban untuk melayani publik;

6. Harga/tarif pelayanan jasa telah ditentukan dalam kontrak dan pemerintah selaku grantor melalui kementerian perhubungan akan mengatur perubahan harga selama periode perjanjian jasa.

\subsection{Permasalahan Akuntansi}

Dalam paragraf 10 ISAK 16 disebutkan mengenai permasalahan yang mungkin akan timbul akibat interpretasi penerapan ISAK 16, adapun permasalahan yang dibahas adalah sebagai berikut:

1. Perlakuan hak operator atas infrastruktur

Infrastruktur tidak diakui sebagai aset tetap dari operator dikarenakan perjanjian jasa kontraktual tidak memberikan hak kepada operator untuk mengendalikan penggunaan infrastruktur layanan publik, operator mengoperasikan infrastruktur 
untuk pelayanan publik untuk kepentingan grantor sesuai persyaratan kontrak. Sehubungan dengan konteks perjanjian Penyelenggaraan Prasarana Kereta Api Ringan, KAI sebagai penyelenggara sesuai ISAK 16 tidak mencatat infrastruktur sebagai aset tetapnya.

2. Jasa pembangunan dan peningkatan infrastruktur

KAI sebagai operator akan mencatat pendapatan dan biaya yang terkait dengan jasa konstruksi atau peningkatan kemampuan sesuai dengan PSAK 34: Kontrak Konstruksi. Dalam Peraturan Presiden Republik Indonesia Nomor 49 Tahun 2017 tentang Perubahan Kedua Atas Peraturan Presiden Nomor 98 Tahun 2015 tentang Percepatan Penyelenggaraan Kereta Api Ringan/Light Rail Transit Terintegrasi Di Wilayah Jakarta, Bogor, Depok, dan Bekasi ditetapkan bahwa KAI bertindak sebagai investor selain sebagai operator sehingga KAI mempunyai kewajiban untuk membangun jalan, menyelesaikan pembangunannya, mengoperasikan dan melakukan perawatan. Ketentuan dalam ISAK 16 menyebutkan pada tahap konstruksi KAI mencatat pendapatan dan biaya konstruksi berdasarkan PSAK 34 Kontrak Konstruksi dengan menggunakan metode percentage of completion, hal ini sesuai denganDSAK (2017f),dalam paragraf 21 PSAK 34 yang menyatakan jika hasil kontrak konstruksi dapat diestimasi secara andal, pendapatan kontrak dan biaya kontrak yang berhubungan dengan kontrak konstruksi diakui masingmasing sebagai pendapatan dan beban dengan memperhatikan tahap penyelesaian aktivitas kontrak pada tanggal akhir periode pelaporan (the stage of completion of the contract activity at the end of the reporting period).

3. Pendapatan dari aktivitas pemberian jasa operasi diakui sesuai dengan pernyataan DSAK (2017d) mengenai PSAK 23: Pendapatan;

4. Imbalan yang diberikan oleh pemberi konsensi kepada operator

Berdasarkan paragraf 15 ISAK 16 yang menyebutkan jika operator melakukan jasa pembangunan atau peningkatan kemampuan, maka imbalan yang diterima atau piutang operator diakui pada nilai wajar. Imbalan dapat berupa hak atas aset keuangan atau aset tidak berwujud dengan ketentuan sebagai berikut:

a. Operator mengakui aset keuangan sejauh operator memiliki hak kontraktual tanpa syarat untuk menerima kas atau aset keuangan lain dari atau atas petunjuk pemberi konsesi untuk jasa konstruksi, pemberi konsesi memiliki sedikit, jika ada, kemampuan untuk menghindari pembayaran, biasanya karena perjanjian dapat dipaksakan secara hukum. Operator memiliki hak tanpa syarat untuk menerima kas jika pemberi konsesi secara kontraktual menjamin untuk membayar operator (a) jumlah yang ditetapkan atau ditentukan; atau (b) kekurangan (shortfall), jika ada, antara jumlah yang diterima dari pengguna layanan publik dan jumlah yang ditetapkan atau ditentukan, walaupun jika pembayaran bergantung (contingent) pada apakah operator telah memastikan infrastruktur memenuhi persyaratan kualitas atau efi siensi yang ditentukan.

b. Operator mengakui aset tidak berwujud sejauh operator tersebut menerima hak (lisensi) untuk membebankan pengguna layanan publik. Suatu hak untuk membebankan pengguna layanan publik bukan merupakan hak tanpa syarat 
untuk menerima kas karena jumlahnya bergantung pada sejauh mana publik menggunakan jasa.

Dalam pasal 396 huruf (2) Peraturan Pemerintah Republik Indonesia Nomor 56 Tahun 2009 tentang Penyelenggaraan Perkeretaapian disebutkan bahwa masyarakat yang mendapatkan pelayanan penyelenggaraan perkeretaapian harus membayar atas pelayanan yang dinikmati sesuai dengan tarif yang diberlakukan oleh penyelenggara perkeretaapian.

Sesuai dengan paragraf 15 ISAK 16 dan pasal 396 huruf (2) Peraturan Pemerintah Republik Indonesia Nomor 56 Tahun 2009 dapat disimpulkan bahwa KAI selaku operator memberikan jasa konstruksi kepada pemberi konsesi dalam hal ini pemerintah yang ditukar dengan aset tidak berwujud, yaitu hak untuk membebankan tarif kepada pengguna jasa. DSAK (2017c), menyatakan bahwa operator mengakui aset tidak berwujud pada biaya perolehan, yaitu pada nilai wajar imbalan yang diserahkan untuk memperoleh aset tersebut, yang merupakan nilai wajar imbalan yang diterima atau dapat diterima atas jasa konstruksi yang diserahkan. Aset tidak berwujud tersebut diamortisasi selama aset tersebut diharapkan tersedia untuk digunakan oleh operator.

5. Biaya Pinjaman

Sesuai dengan DSAK (2017e), biaya pinjaman terkait dengan perjanjian diakui sebagai beban pada periode terjadinya biaya pinjaman tersebut dalam hal operator menerima aset tidak berwujud maka biaya pinjaman dikapitalisasi selama periode konstruksi.

\subsection{Ilustrasi Permasalahan Akuntansi}

Untuk tujuan ilustrasi permasalahan akuntansi, diasumsikan bahwa operator melakukan kegiatan sebagai berikut:

1. Persyaratan penjanjian jasa mensyaratkan KAI selaku operator untuk membangun jalan, menyelesaikan pembagunannya dalam waktu 2 tahun dengan kontrak konstruksi sebesar Rp 1.000 kemudian mengoperasikan dan memeliharanya sesuai standar yang ditetapkan selama 10 tahun setelah konstruksi selesai sesuai dengan masa konsensi dengan biaya sebesar Rp 10 pertahun, maka KAI selaku operator akan mengestimasikan biaya yang akan terjadi untuk memenuhi kewajibannya sebagai berikut:

Tabel 2 Biaya Kontrak

\begin{tabular}{|lcc|}
\hline & Tahun & Rp \\
\hline Jasa Konstruksi & 1 & 500 \\
Jasa operasi (pertahun) & 2 & 500 \\
& $1-10$ & 10 \\
\hline
\end{tabular}

2. Persyaratan perjanjian memperbolehkan operator untuk membebankan tarif kepada pengguna jasa. Operator memperkirakan bahwa jumlah pengguna jasa akan stabil selama masa kontrak dan operator akan menerima tarif sebesar Rp 200 pada setiap tahun dari tahun ke 3-12. Para pengguna jasa membayar layanan 
publik pada saat yang sama ketika mereka menerima jasa tersebut, yaitu ketika mereka menggunakan penyelenggaraan prasarana kereta api ringan. Oleh karena itu KAI sebagai operator mengakui pendapatan ketika menerima tarif.

3. KAI selaku operator memberikan jasa konstruksi kepada pemberi konsesi yang ditukar dengan aset tidak berwujud, yaitu hak untuk membebankan tarif kepada pengguna jasa di tahun ke 3 sampai 12. DSAK (2017c) menyatakan operator mengakui aset tidak berwujud pada biaya perolehan, yaitu pada nilai wajar imbalan yang diserahkan untk memperoleh aset tersebut, yang merupakan nilai wajar imbalan yang diterima atau dapat diterima atas jasa konstruksi yang diserahkan. Selama tahap konstruksi aset operator diklasifikasikan sebagai aset tidak berwujud. KAI mengestimasikan nilai wajar dari imbalan yang diterima sama dengan perkiraan biaya konstruksi. KAI juga mengasumsikan bahwa, sesuai dengan DSAK (2017e), KAI mengkapitalisasi biaya pinjaman, diperkirakan mencapai 7 persen, selama tahap konstruksi dari perjanjian, sehingga pengukuran awal aset tidak berwujud dapat diestimasikan sebagai berikut:

Tabel 3 Pengukuran awal aset tidak berwujud

\begin{tabular}{|lr|}
\hline Jasa Konstruksi pada tahun 1 & Rp \\
\hline Kapitalisasi biaya pinjaman & 35 \\
Jasa Konstruksi pada tahun 2 & 500 \\
Aset tak berwujud pada akhir tahun 2 & 1.035 \\
\hline
\end{tabular}

Sesuai dengan DSAK (2017c), aset tidak berwujud diamortisasi selama infrastruktur tersebut diharapkan tersedia untuk digunakan oleh operator, yaitu tahun ke 3 sampai 12. Jumlah amortisasi aset tidak berwujud (Rp1.035) dialokasikan menggunakan metode garis lurus. Biaya amortisasi tahunan dibebankan sebesar Rp1.035 dibagi 10 tahun, yaitu Rp104 per tahun.

4. KAI mendanai perjanjian sepenuhnya dengan utang dan saldo laba. KAI membayar bunga sebesar 7 persen per tahun atas saldo utang. Jika arus kas dan nilai wajar tetap sama seperti yang diperkirakan, arus kas operator, laporan laba rugi komprehensif dan laporan posisi keuangan operator selama masa perjanjian akan menjadi:

Tabel 4 Arus Kas

\begin{tabular}{|c|c|c|c|c|c|c|c|c|c|c|c|c|c|}
\hline Tahun & 1 & 2 & 3 & 4 & 5 & 6 & 7 & 8 & 9 & 10 & 11 & 12 & Jumlah \\
\hline Penerimaan & 0 & 0 & 200 & 200 & 200 & 200 & 200 & 200 & 200 & 200 & 200 & 200 & 2.000 \\
\hline Biaya Kontrak & -500 & -500 & -10 & -10 & -10 & -10 & -10 & -10 & -10 & -10 & -10 & -10 & -1.100 \\
\hline Biaya Pinjaman & 0 & -35 & -72 & -64 & -60 & -56 & -52 & -48 & -45 & -42 & -39 & -36 & -547 \\
\hline Arus masuk/keluar neto & -500 & -535 & 118 & 126 & 130 & 134 & 138 & 142 & 145 & 148 & 151 & 154 & 353 \\
\hline
\end{tabular}

Tabel 5 Laporan laba rugi komprehensif

\begin{tabular}{|c|c|c|c|c|c|c|c|c|c|c|c|c|c|}
\hline Tahun & 1 & 2 & 3 & 4 & 5 & 6 & 7 & 8 & 9 & 10 & 11 & 12 & Jumlah \\
\hline Pendapatan & 500 & 500 & 200 & 200 & 200 & 200 & 200 & 200 & 200 & 200 & 200 & 200 & 3.000 \\
\hline Amortisasi & 0 & 0 & -104 & -104 & -104 & -104 & -104 & -104 & -104 & -104 & -104 & -104 & -1.035 \\
\hline Biaya Kontrak & -500 & -500 & -10 & -10 & -10 & -10 & -10 & -10 & -10 & -10 & -10 & -10 & -1.100 \\
\hline Biaya Pinjaman & 0 & -35 & -72 & -64 & -60 & -56 & -52 & -48 & -45 & -42 & -39 & -36 & -547 \\
\hline Laba Neto & 0 & -35 & 14 & 22 & 27 & 31 & 35 & 38 & 42 & 45 & 48 & 51 & 318 \\
\hline
\end{tabular}


Tabel 6 Laporan posisi keuangan

\begin{tabular}{|lrrrrrrrrrrrr|}
\hline Tahun & $\mathbf{1}$ & $\mathbf{2}$ & $\mathbf{3}$ & $\mathbf{4}$ & $\mathbf{5}$ & $\mathbf{6}$ & $\mathbf{7}$ & $\mathbf{8}$ & $\mathbf{9}$ & $\mathbf{1 0}$ & $\mathbf{1 1}$ & $\mathbf{1 2}$ \\
\hline Aset tak berwujud & 500 & 1.035 & 932 & 828 & 725 & 621 & 518 & 414 & 311 & 207 & 104 & 0 \\
Kas (Hutang) & -500 & -1.035 & -917 & -853 & -794 & -738 & -686 & -638 & -594 & -552 & -513 & -477 \\
\cline { 2 - 12 } Aset Neto & 0 & 0 & 14 & -25 & -69 & -117 & -169 & -224 & -283 & -345 & -410 & -477 \\
& & & & & & & & & & & & \\
\end{tabular}

Berdasarkan ilustrasi permasalahan akuntansi diatas, terdapat beberapa permasalahan yang akan timbul dari penerapan ISAK 16. Beberapa permasalahan diantaranya adalah sebagai berikut:

1. Permasalahan pengakuan pendapatan

Ketentuan dalam ISAK 16 menyebutkan bahwa pada tahap konstruksi KAI harus mencatat pendapatan dan biaya konstruksi aset tetap berdasarkan PSAK 34: Kontrak Konstruksi dengan menggunakan metode percentage of completion.DSAK (2017f) menyatakan bahwa jika hasil kontrak konstruksi dapat diestimasi secara andal, pendapatan kontrak dan biaya kontrak yang berhubungan dengan kontrak konstruksi diakui masing-masing sebagai pendapatan dan beban dengan memperhatikan tahap penyelesaian aktivitas kontrak pada tanggal akhir periode pelaporan (the stage of completion of the contract activity at the end of the reporting period).

Dari sisi perpajakan, penghasilan jasa konstruksi merupakan objek PPh Final ( $\mathrm{PPh}$ Pasal 4 ayat (2)). Walaupun KAI menerapkan PSAK 34 namun karena KAI tidak memiliki Surat Ijin Usaha Jasa Konstruksi (SIUJK) maka atas KAI tidak dapat diterapkan ketentuan PPh Final. Maka sesuai dengan Pasal 19 PP 94/2010, dalam hal penghasilan tidak dikenai Pajak Penghasilan yang bersifat final, atas penghasilan tersebut dikenai Pajak Penghasilan berdasarkan tarif sebagaimana dimaksud dalam Pasal 17 Undang-Undang Pajak Penghasilan.

KAI harus mengakui pendapatan pada laporan keuangannya namun faktanya karena KAI tidak akan melakukan penagihan kepada pemerintah maka tidak akan ada kas yang diterima oleh KAI. Timbul permasalahan pada saat pelaporan SPT $\mathrm{PPh}$ Badan, apabila pendapatan yang tercatat ternyata terdapat tambahan margin sehingga laporan keuangan KAI pada tahap konstruksi akan berada pada posisi laba dan atas pendapatan tersebut dimasukkan dalam perhitungan PPh Badan maka akan terdapat Pajak Penghasilan terutang yang harus dibayar. Pada kenyataannya selama tahap kontruksi, KAI tidak akan menerima pendapatan sama sekali dari pemerintah. Ditinjau dari sisi keadilan, apabila KAI pada tahap konstruksi sudah diharuskan membayar Pajak Penghasilan sementara belum ada penghasilan yang diterima, maka dari sisi keadilan dapat dikatakan tidak terpenuhi. Kemudian dari sisi saat pemungutan pajak, pajak dipungut pada saat yang tepat yaitu pada saat penghasilan diterima. Dalam konteks KAI, pada masa konstruksi dan sampai dengan berakhirnya masa konsensi tidak akan ada penghasilan yang diterima KAI dari pemerintah.Dengan demikian atas pendapatan konstruksi pada tahap konstruksi berdasarkan ISAK 16 seharusnya dikoreksi fiskal dan pendapatan tersebut dikeluarkan dari perhitungan $\mathrm{PPh}$ terutang dalam SPT PPh Badan. 
2. Permasalahan penurunan nilai aset tidak berwujud

Berdasarkan DSAK (2017c), aset dapat dikategorikan sebagai aset tidak berwujud apabila memenuhi beberapa kriteria antara lain:

a. Keteridentifikasian: aset non-moneter yang dapat di identifikasi tanpa wujud fisik, dapat dipisahkan/dibedakan, atau timbul dari kontrak atau hak legal lainnya.

b. Pengendalian: mampu memperoleh manfaat ekonomis masa depan, dan dapat membatasi akses pihak lain dalam memperoleh manfaat ekonomis tersebut.

c. Manfaat ekonomis masa depan: mencakup Pendapatan dari penjualan barang atau jasa, Penghematan biaya, atau manfaat lain dari penggunaan aset tersebut.

Dalam mengakui suatu item sebagai aset tidak berwujud, entitas perlu menunjukkan bahwa item tersebut memenuhi definisi aset tidak berwujud dan memenuhi kriteria pengakuan. Terdapat kriteria dalam pengakuan, sebagaimana dalam PSAK 19, antara lain kemungkinan besar entitas akan memperoleh manfaat ekonomis masa depan, biaya perolehan aset tersebut dapat diukur secara andal, dalam menilai kemungkinan aset tidak berwujud menggunakan asumsi masuk akal dan dapat dipertanggungjawabkan serta estimasi terbaik manajemen, pengeluaran yang tidak memenuhi kriteria pengakuan diakui sebagai beban selain itu aset tidak berwujud pada awalnya harus diakui sebesar biaya perolehan.

Aset tidak berwujud dapat mempunyai umur terbatas, sehingga perusahaan mengamortisasi aset tidak berwujud yang mempunyai umur terbatas dengan memperhatian diamortisasi dengan biaya sistematis untuk biaya selama masa manfaat, aset kredit akun atau akumulasi amortisasi, masa manfaat harus mencerminkan periode dimana aset akan memberikan kontribusi untuk arus kas. PSAK 19 mengharuskan perusahaan untuk menilai nilai residu dan masa manfaat aset tidak berwujud setidaknya setiap tahun.

Dalam beberapa waktu bisa memungkinkan jumlah tercatat pada aset tidak berwujud tidak dapat dipulihkan, oleh karena itu perusahaan perlu untuk menurunkan nilai tercatatnya.Penurunan nilai aset terjadi apabila nilai buku aset tidak dapat dipulihkan.DSAK (2017g) menyatakan bahwa secaraperiodik perusahaan harus menguji atau mereview ada atau tidaknya indikasi tersebut, maka perusahaan harus menaksir atau mengestimasi jumlah terpulihkan aset tersebut. Untuk setiapaset yang mengalami penurunan nilai, perusahaan akan mencatat kerugian selisih antara nilaibuku aset dengan nilai pasar aset, maka aset diturunkan sebesar nilai wajar (fair value). Permasalahan akan timbul setelah pengujian dan review telah dilakukan oleh KAI, apabila dalam pengujian dan review ditemui indikasi terhadap penurunan nilai aset tidak berwujud maka KAI harus mencatat kerugian selisih antara nilaibuku aset dengan nilai pasar aset, implikasi atas pencatatan kerugian ini adalah akan menurunnya laba perusahaan 
atau bahkan dapat menyebabkan rugi yang cukup signifikan bagi perusahaan. Untuk mengurangi besarnya nilai penurunan aset tidak berwujud ini, KAI harus terus menghasilkan arus kas masa depan dari penggunaan selanjutnya dari aset atau aset lainnya sehingga pengujian dan review dapat mengurangi besarnya kerugian yang mungkin nanti akan di tanggung oleh perusahaan.

\section{Permasalahan Pengakuan Aset Tetap}

Paragraf 11 ISAK 16 menyatakan bahwa infrastruktur, dalam ruang lingkup Interpretasi ISAK 16, tidak akan diakui sebagai aset tetap, hal ini dikarenakan perjanjian jasa kontraktual tidak memberikan hak kepada operator untuk mengendalikan penggunaan infrastruktur layanan publik, operator hanya memiliki akses mengoperasikan infrastruktur untuk menyediakan layanan publik untuk kepentingan pemberi konsesi sesuai dengan persyaratan yang ditentukan dalam kontrak. Dengan adanya ketentuan ini, KAI sebagai operator tidak mencatat infrastruktur sebagai asetnya.

Apabila dilihat dalam DSAK (2017b)paragraf 6, pengertian aset tetap adalah aset berwujud yang:

a) Dimiliki untuk digunakan dalam produksi atau penyediaan barang atau jasa, untuk direntalkan kepada pihak lain, atau untuk tujuan administratif; dan

b) Diperkirakan untuk digunakan selama lebih dari satu periode.

Sesuai ketentuan diatas, infrastruktur Light Rail Transit (LRT) telah memenuhi persyaratan untuk diterapkan sebagai aset tetap, hal ini dikarenakan LRT akan digunakan KAI lebih dari satu periode atau selama masa konsensi, selain itu juga digunakan dalam penyediaan jasa.

Dengan adanya 2 ketentuan tersebut akan menimbulkan permasalahan apakah aset tetap harus dicatat atau tidak. Seharusnya Dewan Standar Akuntansi Keuangan (DSAK) memberikan penegasan atas risiko yang dihadapi setelah terbitnya ISAK 16.

\section{KESIMPULAN, SARAN, DAN KETERBATASAN PENELITIAN}

Berdasarkan pembahasan sebelumnya dapat disimpulkan sebagai berikut:

1. Sesuai dengan kerangka akuntansi ISAK 16 dan berdasarkan Peraturan Pemerintah Republik Indonesia Nomor 56 Tahun 2009 tentang Penyelenggaraan Perkeretaapian dan Peraturan Menteri Perhubungan Republik Indonesia Nomor PM 15 tahun 2016 tentang Konsesi dan Bentuk Kerjasama Lainnya antara Pemerintah dan Badan Usaha di Bidang Perkeretaapian Umum, atas perjanjian Penyelenggaraan Prasarana Kereta Api Ringan dapat dikatakan telah memenuhi persyaratan untuk menerapkan ISAK 16: Perjanjian Konsensi Jasa. 
2. Konsekuensi atas penerapan ISAK 16 bagi perusahaan adalah akan terdapatnya permasalahan akuntansi. Permasalahan akuntansi yang akan dihadapi yaitu permasalahan pengakuan pendapatan,penurunan nilai aset tidak berwujud dan permasalahan pengakuan aset tetap.

Atas permasalahan yang timbul dari penerapan ISAK 16 diatas, saran yang diajukan oleh penulis adalah sebagai berikut:

1. Pendapatan konstruksi pada tahap konstruksi berdasarkan ISAK 16 dikoreksi fiskal dan pendapatan tersebut dikeluarkan dari perhitungan $\mathrm{PPh}$ terutang dalam SPT PPh Badan.

2. Kerugian akibat adanya penurunan nilai dari aset tidak berwujud dapat diminimalisir dengan terus menghasilkan arus kas masa depan dari penggunaan selanjutnya dari aset atau aset lainnya sehingga pengujian dan review dapat mengurangi besarnya kerugian yang mungkin nanti akan di tanggung oleh perusahaan.

3. Meminta penjelasan dan penegasan kepada Dewan Standar Akuntansi Keuangan (DSAK) atas permasalahan pengakuan aset tetap.

Penelitian yang dilakukan saat ini masih memiliki keterbatasan, keterbatasan utama adalah dalam penelitian ini dasar analisis bukan berdasarkan perjanjian antara Kementerian Perhubungan yang diwakili oleh Direktur Jenderal Perkeretaapian dengan KAI namun terbatas hanya analisis terhadap Peraturan Presiden Republik Indonesia Nomor 49 Tahun 2017 tentang Perubahan Kedua Atas Peraturan Presiden Nomor 98 Tahun 2015 tentang Percepatan Penyelenggaraan Kereta Api Ringan/Light Rail Transit Terintegrasi Di Wilayah Jakarta, Bogor, Depok, dan Bekasi, Peraturan Menteri Perhubungan Republik Indonesia Nomor PM 15 tahun 2016 tentang Konsesi dan Bentuk Kerjasama Lainnya antara Pemerintah dan Badan Usaha di Bidang Perkeretaapian Umum dan Peraturan Pemerintah Republik Indonesia Nomor 56 Tahun 2009 tentang Penyelenggaraan Perkeretaapian sehingga imbalan yang diberikan oleh pemberi konsensi kepada operator belum dapat dipastikan. Penulis berharap dalam penelitian selanjutnya perjanjian antara Kementerian Perhubungan yang diwakili oleh Direktur Jenderal Perkeretaapian dengan KAI tentang Perjanjian Penyelenggaraan Prasarana Kereta Api Ringan bisa dilakukan analisis sehingga dapat dipastikan kembali legalitas imbalan yang diberikan oleh pemberi konsensi kepada operator.

\section{DAFTAR PUSTAKA}

Bousquet, F., \& Fayard, A. (2001). Road infrastructure concession practice in Europe (Vol. 2675): World Bank Publications.

DSAK. (2017a). Interpretasi Standar Akuntansi Keuangan (ISAK) 16 : Perjanjian Konsensi Jasa: Ikatan Akuntan Indonesia.

DSAK. (2017b). Pernyataan Standar Akuntansi Keuangan (PSAK) 16 : Aset Tetap: Ikatan Akuntan Indonesia.

DSAK. (2017c). Pernyataan Standar Akuntansi Keuangan (PSAK) 19 : Aset Tak Berwujud: Ikatan Akuntan Indonesia. 
DSAK. (2017d). Pernyataan Standar Akuntansi Keuangan (PSAK) 23 : Pendapatan: Ikatan Akuntan Indonesia.

DSAK. (2017e). Pernyataan Standar Akuntansi Keuangan (PSAK) 26 : Biaya Pinjaman: Ikatan Akuntan Indonesia.

DSAK. (2017f). Pernyataan Standar Akuntansi Keuangan (PSAK) 34 : Kontrak Konstruksi: Ikatan Akuntan Indonesia.

DSAK. (2017g). Pernyataan Standar Akuntansi Keuangan (PSAK) 48 : Penurunan Nilai Aset: Ikatan Akuntan Indonesia.

Frans, M. N., Ginting, S. E., \& Riwoe, J. C. (2014). Perjanjian Konsesi Jasa: Studi Kasus Perhitungan ISAK 16 dI PT. Telkom. Finance \& Accounting Journal, Vol. 3 No. 1.

Komives, K. (2001). Designing pro-poor water and sewer concessions: early lessons from Bolivia. Water Policy, 3(1), 61-79.

Melati, H. R., \& Christine Tjen, S., Ak., M.Int., Tax., CA. (2015). Analisis Dampak Penerapan ISAK 16: Perjanjian Konsensi Jasa terhadap Pajak Penghasilan Perusahaan IPP. Akuntan Indonesia, Maret-April, 62-66.

Moretto, M., \& Dosi, C. (2007). Concession bidding rules and investment time flexibility. PII. (2014). Kemitraan Pemerintah Swasta Panduan Referensi: PT. Penjaminan Infrastruktur Indonesia (Persero).

Setyosari, P. (2010). Metode Penelitian Pendidikan dan Pengembangan. Jakarta: Kencana.

Sugiyono. (2004). Metode Penelitian Bisnis. Bandung: Ikatan Penerbit Indonesia. 